\title{
Utilization of date by-products in the food industry
}

\author{
Zein Najjar ${ }^{1}$, Constantinos Stathopoulos ${ }^{1 *}$, Suwimol Chockchaisawasdee ${ }^{2}$ \\ ${ }^{1}$ Department of Food Science, College of Food and Agriculture, UAE University, UAE, ${ }^{2}$ College of Health Sciences, Abu Dhabi University, UAE
}

\section{A B S T R A C T}

\begin{abstract}
The fruit of date palm tree Phoenix dactylifera is among the most abundant fruits, and it is rich in essential nutrients. Quality-wise, not all cultivated date fruits meet the commercial standards, and tons of date fruit that are immature, or of poor appearance but with no reduced nutritive value are treated as date by-product and are being used for animal feed or are discarded during processing by the relevant industries. Together with the rejected fruit, date seed which is the inedible part, and the trimmed fronds of the date palm, they are all discarded, resulting in an environmental problem, and an economical loss. The objective of this review is to identify current practices on the uses of low-grade date, seed, and frond in the industry. The literature shows date fruit of low quality is typically processed to make date paste and date syrup, and both are well utilized in the food sector. The chemical composition of date seed, and increasingly of other parts are well known, and fully exploited in many industrial applications.
\end{abstract}

Keywords: Date palm tree; Date by-products; Date paste; Date syrup; Date seed

\section{INTRODUCTION}

Date palm tree, Phoenix dactylifera, is one of the oldest cultivated plants, and the main staple and ancient crops are grown in many regions; in southwest Asia, North Africa, Australia, Mexico, South America, and in southern Africa (Chao and Krueger 2007; Al-Harrasi et al. 2014; Hazzouri et al. 2015). Due to its high tolerance of aridity and very harsh climatic conditions, date palm tree invaluably provides the people in those regions a nutritious food source and environmental protection (Daoud et al. 2019; Kalbouneh 2011). The date fruit is known to be nutrient-rich (Chao and Krueger 2007). It is a good source of carbohydrates (approximately $70 \%$, in the forms of fructose and glucose), dietary fibers (predominantly insoluble fibers), proteins, and minerals (Al-Harrasi et al. 2014; Siddiq 2014; Eoin 2016). It is also rich in phenolic acids, flavonoids, procyanidins, carotenoids, and sterols (Baliga et al. 2011; Gheisari, Heydari, and Basiri 2020).

On average of 5 years after propagation, date fruit can be obtained from a female tree, yielding 400-600 kg/tree annually (Al-Alawi et al. 2017). Date fruit is being harvested and marketed depending on the cultivar at three developmental stages (Fig. 1), which include Khalal (mature firm), Rutab (soft brown), and Tamr (hard raisin-like) (Awad 2007; Glasner et al. 1999).
During cultivation, different ripening stages are found within the same cluster, including immature dates (Lobo, Yahia, and Kader 2013). Thus, date production generates substantial fruit losses (approximately 30\%) during picking, storing, or conditioning the fruits. Due to the large quantity of second-grade date, together with other inedible parts combined at harvesting, it would be beneficial for farmers and the food industry to valorize this by-product by utilizing its nutritional value into value-added products, which at the same time is beneficial to the environment.

This review provides an overview of the potential applications of date by-products (fruit, seed, and leave), and summarizes their incorporation in the industry.

\section{DATE BY-PRODUCTS}

\section{Low-grade date}

Studies on health benefits of date fruit, such as chemoprevention of cancer, prevention of diabetes, and cardiovascular diseases have been investigated (Chao and Krueger 2007; Al-Alawi et al. 2017). Date fruit contains phytochemicals which have cholesterol-lowering properties and antioxidant activity (Tiwari, Brunton, and Brennan 2013). It is involved in traditional medicine as a stimulator

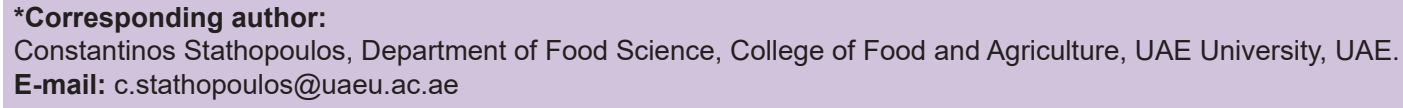




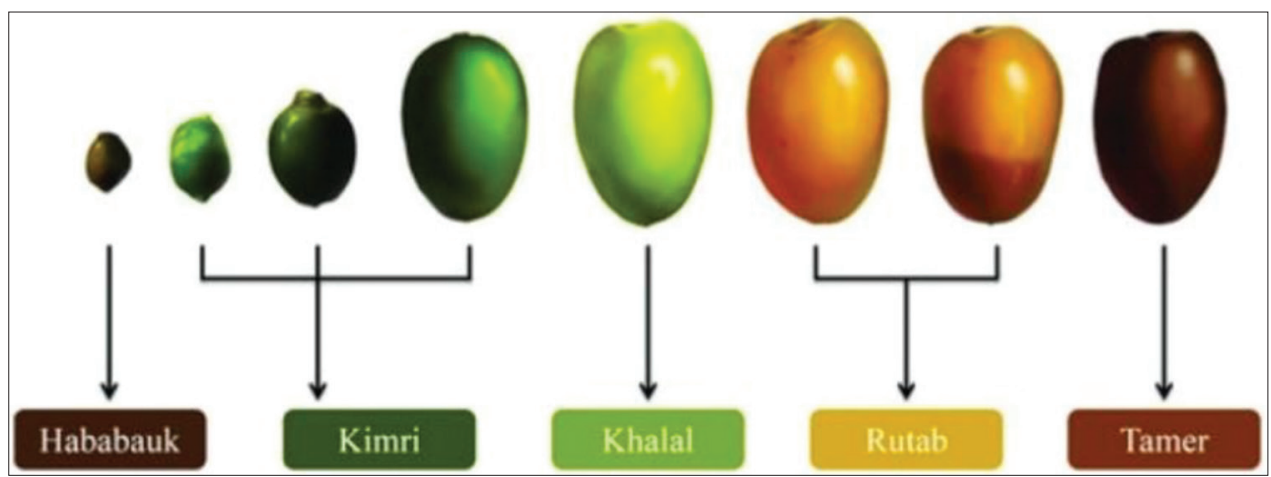

Fig 1. Growth stages of date fruit (Siddiq 2014).

of immune, and it shows antifungal, antiviral, antibacterial, antiparasitic, hepatoprotective, anti-inflammatory, and anticoccidial activities (Puri et al. 2000; Mohamed, Awad, and Adel 2014).

The lost date at harvest (or second-grade date) is a lowgrade date, either hard in texture or contaminated with fungi or infested by insects; such date fruit is not marketed for human consumption, but discarded, and often used in animal feeding (Chandrasekaran and Bahkali 2013; Siddiq 2014).

The second-grade date that is safe for consumption can be used to prepare many products, such as date paste, date juice concentrates (spread, syrup, and liquid sugar, which are being used mainly in bakery and confectionary), and in the production of fermented products like wine, alcohol, vinegar and organic acids (Chandrasekaran and Bahkali 2013). For non-food applications, second-grade date fruit can be used as a substrate for biogas production like methane (Lattieff 2016; Abd-Alla and Elsadek El-Enany 2012). Table 1 lists the possible uses of date by-products.

\section{Date syrup}

Low-quality date fruit serves as a good source of dry matter, sugars, and phenolic compounds, and can be used to make high value-added products like syrup (Fig. 2; (Chandrasekaran and Bahkali 2013). According to the 2013 Iran National Standard Organization, date syrup must have the following standards: a minimum Brix of 70 , a $\mathrm{pH}$ in the range of 4.2 to 6 , a maximum ash content of $2 \%$, and a minimum reducing sugars of 58\% (Farahnaky et al. 2016).

Date syrup can be used as an ingredient in some food formulations like ice cream, beverages, bakery products, jam, and butter (Barreveld 1993; Jridi et al. 2015; Razavi, Habibi Najafi, and Alaee 2007). Due to its high fiber and sugar contents, the incorporation of date syrup and date powder in desserts creates a sweetening effect, enhances viscosity, and spontaneous exudation (Ashraf and HamidiEsfahani 2011; Tang, Shi, and Aleid 2013; Elleuch et al.

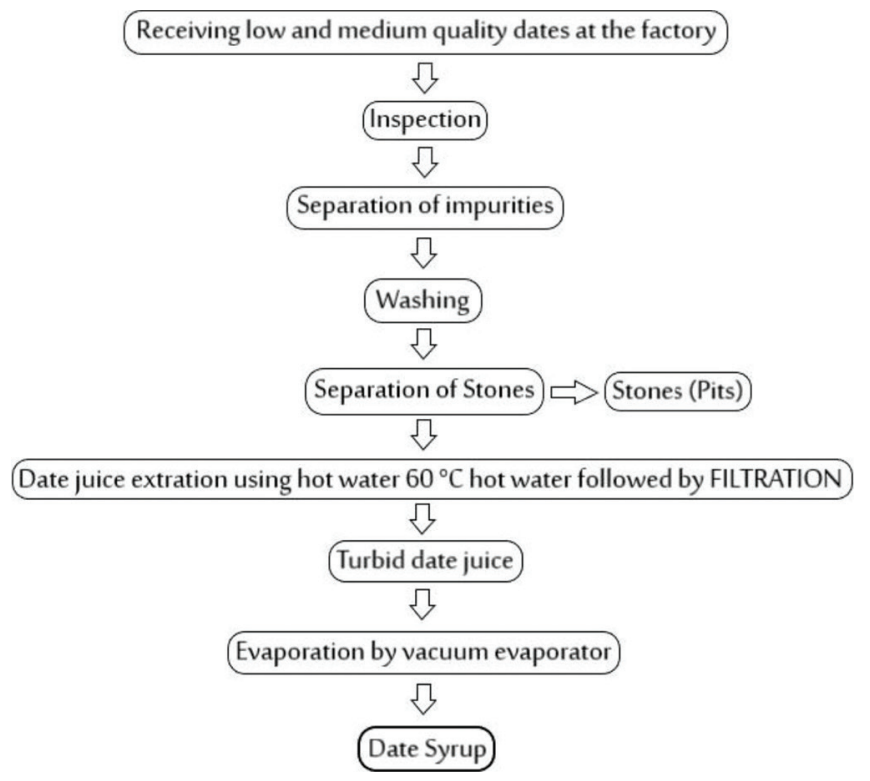

Fig 2. Large scale process chart of production of date syrup [adapted from (Farahnaky et al. 2016).

2008). It is also used as a natural coloring and flavoring agent. A study on the effects of date syrup and date powder in a dairy dessert showed the physicochemical, phytochemical, microbiological, rheological, and microstructural properties of the date-added products differed from those of the commercial sample tested (Djaoud et al. 2020). Date syrup was reported to be suitable for replacing sugar in some traditional Indian and Iranian desserts (Manickvasagan, Chandini, and Al Attabi 2018; Ardali and Akbarian 2014). Improvement of organoleptic properties and chemical composition in products such as prebiotic chocolate milk and yogurt after addition of date syrup was observed (Kazemalilou and Alizadeh 2017; El-Nagga and Abd ElTawab 2012; Sayed, Kholif, and S. 2010).

Date syrup contains several components that are crucial for microbial growth, e.g. simple sugars (glucose, fructose, sucrose), vitamins (B1, B2, nicotinic acid), potassium, and chloride (Al Eid 2006). Thus, it has been used in biomass production and microbial fermentation process. Reports on 
Table 1: The main uses of date by-products

\begin{tabular}{|c|c|c|}
\hline \multicolumn{2}{|l|}{ Date by-product } & \multirow[b]{2}{*}{$\begin{array}{l}\text { Possible use } \\
\text { Ice cream, beverages, baked products, jam, butter (Barreveld 1993; Jridi et al. 2015; Razavi, Habibi } \\
\text { Najafi, and Alaee 2007; Gheisari, Heydari, and Basiri 2020; Tammam, Salman, and Abd-El-Rahim } \\
\text { 2014) } \\
\text { Dairy desserts (Djaoud et al. 2020), traditional desserts (Manickvasagan, Chandini, and Al Attab } \\
\text { 2018; Ardali and Akbarian 2014) } \\
\text { Prebiotic Milk (Kazemalilou and Alizadeh 2017) } \\
\text { Yogurt (El-Nagga and Abd EITawab 2012; Tammam et al. 2013) } \\
\text { Carbon source for bacterial fermentation (Ben Salah et al. 2011; Elsanhoty, Al-Turki, and Ramadan } \\
\text { 2012; Khiyami, Alfadul, and Bahkali 2011) Source of biogas } \\
\text { (Jaafar 2010; Lattieff 2016) }\end{array}$} \\
\hline Low-grade date & Date syrup & \\
\hline & Date paste & $\begin{array}{l}\text { Enhancing cooked meat (Sánchez-Zapata et al. 2011) } \\
\text { Date jam (Besbes et al. 2009) }\end{array}$ \\
\hline & Date fiber & $\begin{array}{l}\text { Ice cream industry (Yangılar 2015) } \\
\text { Baked goods (Mrabet et al. 2016) }\end{array}$ \\
\hline & Spoiled date & Acetone, butanol, and ethanol production (Abd-Alla and Elsadek El-Enany 2012) \\
\hline \multirow[t]{2}{*}{ Date seed } & Date seed components & $\begin{array}{l}\text { Animal and poultry feed (Vandepopuliere, Al-Yousef, and Lyons 1995) } \\
\text { Yeast growth (Bkary et al. 2018) } \\
\text { Pita bread (Platat et al. 2015) } \\
\text { Polyols production (Briones et al. 2011) } \\
\text { Pollutants treatment (Alhamed 2009; Ahmed 2016; Al-Ghouti et al. 2017) }\end{array}$ \\
\hline & Date seed oil & $\begin{array}{l}\text { Cooking and frying (Nehdi et al. 2018) } \\
\text { Producing margarine (Nehdi et al. 2010) } \\
\text { Replaces oil in Mayonnaise (Basuny and Al-Marzooq 2011) } \\
\text { Cosmetics (Lecheb and Benamara 2015) } \\
\text { Biodegradable polyester (Al-Muhtaseb et al. 2018) }\end{array}$ \\
\hline
\end{tabular}

microbial fermentation using date by-products as substrates can be found, for example, curdlan gum production by Rhizobium radiobacter ATCC $6466^{\mathrm{TM}}$ using date juice (Ben Salah et al. 2011), carotenoid production by Lactobacillus plantarum using lost date at Tamr stage (Elsanhoty, Al-Turki, and Ramadan 2012), bleomycin production by Streptomyces mobaraensis ATCC 15003 using date syrup (Radwan et al. 2010), xanthan gum production by Xanthomonas campestris NRRL B-1459 using date juice by-products (Ben Salah et al. 2010), polyhydroxyalkanoates production by Bacillus spp. using date syrup (Khiyami, Alfadul, and Bahkali 2011). Those studies indicated that the date fruit by-products exhibit promising potentials to be used as cost-effective substrates.

Apart from being a suitable substrate for the growth of some microorganisms, date syrup has also been reported for exhibiting antimicrobial activity. A study demonstrated date syrup sterilized by acetone and the polyphenolic components extracted from that sterile date syrup were able to inhibit the growth of Escherichia coli and Staphylococcus aureus by inducing oxidative stress in bacteria through hydrogen peroxide generation (Taleb et al. 2016).

\section{Date paste}

Low-quality date can be processed into date paste, which is, similar to date fruit, high in sugar content, total and insoluble dietary fiber, and natural antioxidants. Due to its dietary fiber content, date paste exhibits functional properties, e.g. water holding capacity, oil holding capacity, emulsifying activity, gel formation, and pseudoplastic behavior of its suspension, which are necessary for the formulation of certain food products (Elleuch et al. 2008; Hussein and Ali 2017). Applications of date paste into various food products, such as meat, bakery, and confectionery, have been explored. The incorporation of date paste in cooked meat decreases fat content and increases total dietary fibers resulting in more adhesive, less hard, chewy, and cohesive product (Sánchez-Zapata et al. 2011). The addition of fresh date paste into certain meat products may suppress lipid and pigment oxidation during storage (Martín-Sánchez et al. 2013). Due to its high sugar content, date paste can also be used in manufacturing value-added products like date jam (Besbes et al. 2009), and date candy (Shi, Shahidi, and Ho 2005). In baked goods, the addition of date paste helps improving dough rheological properties, retarding retrogradation, and prolonging shelf life (Shi, Shahidi, and Ho 2005; Ahmed and Ramaswamy 2006).

\section{Date fiber}

Date fruits contain high total dietary fiber, of which 80 $90 \%$ is an insoluble fraction. Depending on the variety, stage of maturation, extraction methods, and the total dietary fiber content of date fruit varies from 6 to $11 \%$ (Al-Shahib and Marshall 2003; Al-Farsi and Lee 2008; Tang, Shi, and Aleid 2013; Al-Farsi et al. 2007).

Applications of date fibers in food products have been investigated, for example, in ice cream (Yang1lar 2015), and baked goods (Mrabet et al. 2016). Improvement in rheological property and texture in such products was noted. 


\section{Spoiled date fruit}

Spoilt date fruit, albeit unsuitable for human consumption, still contains several essential components for the growth of microorganisms and can be efficiently used as a substrate to produce acetone, butanol, and ethanol (Abd-Alla and Elsadek El-Enany 2012).

\section{Date seed}

Date seed is considered as waste (Besbes et al. 2004). It accounts for $10-15 \%$ of total date fruit mass on average, depending on maturity, variety, and grade (Besbes et al. 2004; Al-Shahib and Marshall 2003). Date seed represents a significant amount of waste, considering global date fruit production was more than 8 million tons in 2018 (FAOSTAT 2018). Therefore, over 800,000 tons of date seed could be produced. Conventionally, date seed is generally used either as animal and poultry feed or soil fertilizer (Vandepopuliere, Al-Yousef, and Lyons 1995).

Chemical composition analysis showed that, by weight, date seed contains $60-80 \%$ fiber, $4-14 \%$ oil, and a low proportion of protein. A wide range of phytochemicals such as alkaloids, flavonoids, anthraquinone, saponin, terpenoids, and tannin are present in date seed, in addition to the essential minerals like potassium and calcium (Hamada, Hashim, and Sharif 2002; Al-Farsi and Lee 2008; Al-Farsi et al. 2007). These findings present a new opportunity to reconsider the use of date seed in higher value-added products.

There is a wide range for date seed utilization, in the food and non-food industry. A study on the use of date seed components and flesh to cultivate bakers' yeast biomass reported date components served as good carbon and nitrogen source for the fermentation process and gave promising yield (Nancib, Nancib, and Boudrant 1997). Date seed can be processed into powder form and can be used as a cost-effective ingredient to increase crude fiber and minerals in cereal snacks and baked products (Hussein and Ali 2017; Platat et al. 2015). Besides food applications, date seed can be chemically modified to produce polyols, which can be applied to many other industries, e.g. furniture, packing, and transportation (Briones et al. 2011). In water treatment applications, date seed can be converted into activated carbon, exhibiting good adsorbent properties for removal of pollutants (synthetic dyes, heavy metals) from wastewater (Alhamed 2009; Ahmed 2016), and brominated toxic by-products from drinking water (Al-Ghouti et al. 2017).

\section{Date seed oil}

Date seed oil can be extracted with different methods, e.g. soxhlet extraction (Ali, Al-Hattab, and Al-Hydary 2015; Al-Sumri et al. 2017), supercritical fluid extraction (King
2014), green ecological method (Ben-Youssef et al. 2017; Jadhav et al. 2016), and ultrasonic-assisted extraction (Vinatoru 2001).

There are several applications for date seed oil. In food applications, it can be used for cooking, frying, and seasoning, and as an alternative to palm olein (Nehdi et al. 2018), margarine production (Nehdi et al. 2010), and corn oil replacement in mayonnaise production (Basuny and AlMarzooq 2011). In cosmetic applications, it is feasible to incorporate date seed oil in the formulation of cosmetic creams [80]. In petrochemical applications, it has been used in biodiesel production and studies indicated the quality of the biodiesels produced to meet the limits of the regulatory standards (Azeem et al. 2016; Al-Zuhair et al. 2017; Al-Muhtaseb et al. 2018). In another study, date seed oil was successfully used as a sole carbon source for the growth of Cupriavidus necator for the production of Poly (3)-hydroxybutyrate, which is a biodegradable polymer (Yousuf and Winterburn 2017).

\section{Date palm frond}

The date palm tree is known to produce large quantities of agricultural waste; around $20 \mathrm{~kg}$ of dry leaves every tree produces per year that is usually burned in farms resulting in a serious threat for the environment (Tang, Shi, and Aleid 2013), but it was reported that date palm frond has good potential for ruminants (El Hag and $\mathrm{Al}$ Shargi 1998), it can be successfully used to feed local sheep (Mahgoub et al. 2005; Mahgoub et al. 2004). It is used as a supplement to traditional feed (soya and maize) for lamb without affecting the flavor of the meat (Myhara et al. 2000).

The date palm frond composes of cellulose, hemicellulose, and lignin (Saadaoui et al. 2013). Recently it is of interest as a renewable source for cost-effective and green lignocellulosic fibers and composites, which opens a new avenue for waste valorization (Agoudjil et al. 2011). Under certain treatment conditions, the midrib of date palm frond (Fig. 3) is suitable for making wood-cement boards (Nasser and Al-Mefarrej 2011). Different parts of the frond (leaflet, rachis, and leaf sheath) and tree surface fiber (fibrillum) can be transformed into particleboard composites with satisfactory mechanical properties, especially those made from the fibrillum and rachis due to their high amount of lignin (Saadaoui et al. 2013).

Date palm tree fibers have the potential for water treatment applications. Rachis can be structurally modified into sodium carboxymethylcellulose $(\mathrm{CMCNa})$, which acts as an eco-friendly flocculant to remove turbidity in drinking water treatment (Khiari et al. 2010). Satisfactory performance of date palm fiber on the reduction of turbidity and chemical 


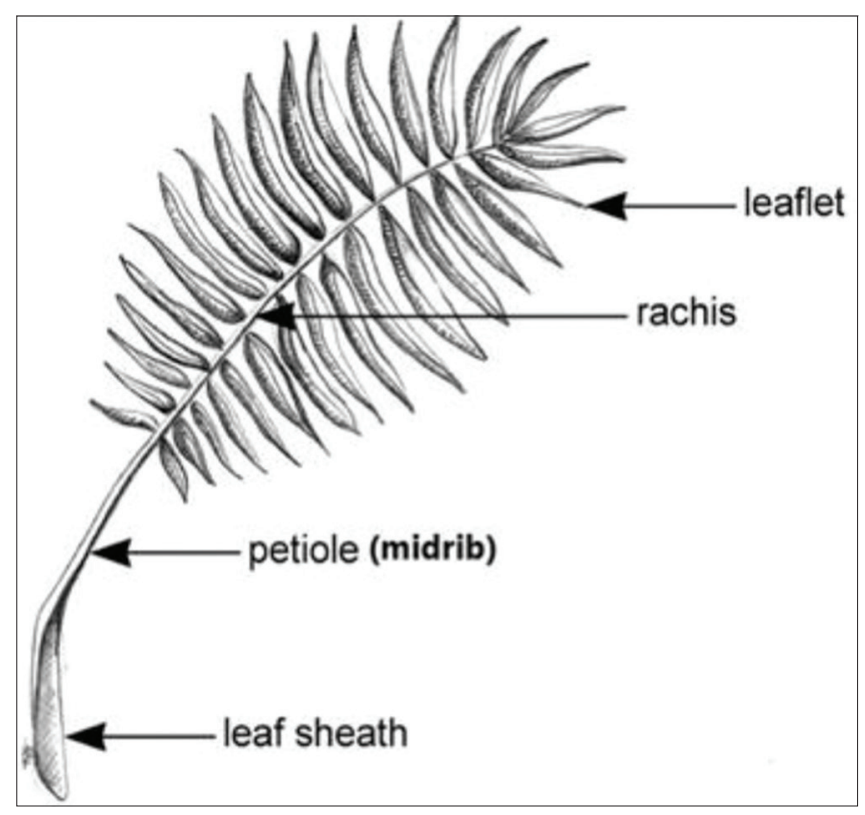

Fig 3. Diagram of date palm frond structure (Anderson 2010).

oxygen demand (COD) in wastewater was observed (Riahi, Mammou, and Thayer 2009). In the automotive industry, date palm fiber shows competitive mechanical properties in comparison to other natural fibers (coir, hemp, and sisal) (Al-Oqla and Sapuan 2014). Petiole and bunch exhibit good insulating properties and have potential for the construction industry (Agoudjil et al. 2011).

\section{CONCLUSIONS}

Date palm cultivation is of high importance in the Middle East, Africa, South America, and recently, Australia. In some regions, apart from being a staple food, the tree serves the people in many other aspects. Harvesting date palm fruit generates a significant amount of waste, which is a burden to the environment. At present, fruit that does not meet the market value, as well as other inedible parts, are relatively well exploited in many industrial applications. The literature shows creativity in date waste valorization. Nevertheless, more opportunities to exploit date waste fora novel and high-market-value products are still available.

\section{SUPPLEMENTARY MATERIALS}

None

\section{AUTHOR CONTRIBUTIONS}

All authors contributed in writing and editing the manuscript.

\section{FUNDING}

This review was part of the Start-up project fund (G00002958) granted to Constantinos Stathopoulos by UAEU.

\section{ACKNOWLEDGMENTS}

The financial support of UAEU through grant G00002958 is gratefully acknowledged.

\section{CONFLICTS OF INTEREST}

None.

\section{REFERENCES}

Abd-Alla, M. H. and A. W. E. El-Enany. 2012. Production of acetonebutanol-ethanol from spoilage date palm (Phoenix dactylifera L.) fruits by mixed culture of Clostridium acetobutylicum and Bacillus subtilis. Biomass Bioenergy. 42: 172-178.

Agoudjil, B., A. Benchabane, A. Boudenne, L. Ibos and M. Fois. 2011. Renewable materials to reduce building heat loss: Characterization of date palm wood. Energy Build. 43: 491-497.

Ahmed, J. and H. S. Ramaswamy. 2006. Physico-chemical properties of commercial date pastes (Phoenix dactylifera). J Food Eng. 76: 348-352.

Ahmed, M. J. 2016. Preparation of activated carbons from date (Phoenix dactylifera L.) palm stones and application for wastewater treatments: Review. Proc. Saf. Environ. Prot. 102: 168-182.

Al-Alawi, R. A., J. H. Al-Mashiqri, J. S. M. Al-Nadabi, B. I. Al-Shihi and Y. Baqi. 2017. Date palm tree (Phoenix dactylifera L.): Natural products and therapeutic options. Front. Plant Sci. 8: 845.

Al Eid, S. M. 2006. Chromatographic separation of fructose from date syrup. Int. J. Food Sci. Nutr. 57: 83-96.

Al-Farsi, M., C. Alasalvar, M. Al-Abid, K. Al-Shoaily, M. Al-Amry and F. Al-Rawahy. 2007. Compositional and functional characteristics of dates, syrups, and their by-products. Food Chem. 104: 943-947.

Al-Farsi, M. A. and C. Y. Lee. 2008. Nutritional and functional properties of dates: A review. Crit. Rev. Food Sci, Nutr. 48: 877-887.

Al-Ghouti, M. A., Z. A. Al Disi, N. Al-Kaabi and M. Khraisheh. 2017. Mechanistic insights into the remediation of bromide ions from desalinated water using roasted date pits. Chem. Eng. J. 308: 463-475.

Alhamed, Y. A. 2009. Adsorption kinetics and performance of packed bed adsorber for phenol removal using activated carbon from dates' stones. J. Hazardous Mater. 170: 763-770.

Al-Harrasi, A., N. U. Rehman, J. Hussain, A. L. Khan, A. Al-Rawahi, S. A. Gilani, M. Al-Broumi and L. Ali. 2014. Nutritional assessment and antioxidant analysis of 22 date palm (Phoenix dactylifera) varieties growing in Sultanate of Oman. Asian Pac. J. Trop. Med. 7s1: S591-S598.

Ali, M. A., T. A. Al-Hattab and I. A. Al-Hydary. 2015. Extraction of date palm seed oil (Phoenix Dactylifera) by soxhlet apparatus. Int. J. Adv. Eng. Technol. 8: 261-271.

Al-Muhtaseb, A., F. Jamil, L. AlHaj, M. T. Z. Myint, E. Mahmoud, M. Ahmad, A. Hasan and S. Rafiq. 2018. Biodiesel production 
over a catalyst prepared from biomass-derived waste date pits. Biotechnol. Rep. 20: e00284.

Al-Oqla, F. M. and S. M. Sapuan. 2014. Natural fiber reinforced polymer composites in industrial applications: Feasibility of date palm fibers for sustainable automotive industry. J. Clean. Prod. 66: 347-354.

Al-Shahib, W. and R. J. Marshall. 2003. The fruit of the date palm: its possible use as the best food for the future? Int. J. Food Sci. Nutr. 54: 247-259.

Al-Sumri, A., N. Al-Siyabi, R. Al-Saadi, S. Al-Rasbi and A. Al-Dallal. 2017. Study on the extraction of date palm seed oil using soxhlet apparatus. Int. J. Sci. Eng. Res. 7: 1266.

Al-Zuhair, S., H. Taher, S. Al-Dhaheri, S. Wajeeh, M. Nour, E. El-Najjar and S. Hasan. 2017. Biodiesel production from oils extracted from date pits. Green Sustain. Chem. 7: 71004.

Ardali, F. R. and M. Akbarian. 2014. The influence of date syrup on color, texture and sensory properties of Gaz. Bull. Environ. Pharmacol. Life Sci. 3: 159-163.

Ashraf, Z. and Z. Hamidi-Esfahani. 2011. Date and date processing: A review. Food Rev. Int. 27: 101-133.

Awad, M. A. 2007. Increasing the rate of ripening of date palm fruit (Phoenix dactylifera L.) cv. Helali by preharvest and postharvest treatments. Postharvest Biol. Technol. 43: 121-127.

Azeem, M. W., M. A. Hanif, J. N. Al-Sabahi, A. A. Khan, S. Naz and A. ljaz. 2016. Production of biodiesel from low priced, renewable and abundant date seed oil. Renew. Energy. 86: 124-132.

Baliga, M. S., B. R. V. Baliga, S. M. Kandathil, H. P. Bhat and P. K. Vayalil. 2011. A review of the chemistry and pharmacology of the date fruits (Phoenix dactylifera L.). Food Res. Int. 44: $1812-1822$.

Barreveld, W. H. 1993. Date palm products. In: FAO Agricultural Services Bulletin No. 101. Food and Agriculture Organization, United Nations.

Basuny, A. M. M. and M. A. Al-Marzooq. 2011. Production of mayonnaise from date pit oil. Food Nutr. Sci. 2: 938-943.

Ben Salah, R., K. Chaari, S. Besbes, N. Ktari, C. Blecker, C. Deroanne and H. Attia. 2010. Optimisation of xanthan gum production by palm date (Phoenix dactylifera L.) juice by-products using response surface methodology. Food Chem. 121: 627-633.

Ben Salah, R., B. Jaouadi, A. Bouaziz, K. Chaari, C. Blecker, C. Derrouane, H. Attia and S. Besbes. 2011. Fermentation of date palm juice by curdlan gum production from Rhizobium radiobacter ATCC 6466 (TM): Purification, rheological and physico-chemical characterization. Lebensm. Wiss. Technol. 44: 1026-1034.

Ben-Youssef, S., J. Fakhfakh, C. Breil, M. Abert-Vian, F. Chemat and N. Allouche. 2017. Green extraction procedures of lipids from Tunisian date palm seeds. Ind. Crops Prod. 108: 520-525.

Besbes, S., C. Blecker, C. Deroanne, N. E. Drira and H. Attia. 2004. Date seeds: Chemical composition and characteristic profiles of the lipid fraction. Food Chem. 84: 577-584.

Besbes, S., L. Drira, C. Blecker, C. Deroanne and H. Attia. 2009. Adding value to hard date (Phoenix dactylifera L.): Compositional, functional and sensory characteristics of date jam. Food Chem. 112: 406-411.

Bkary, M., A. E. R. Metwaly, M. Syed and H. Ghazzawy. 2018. Use of rejects of date palm factories to bakery yeast production. Int. J. Biosci. 12: 269-274.

Briones, R., L. Serrano, R. Ben Younes, I. Mondragon and J. Labidi. 2011. Polyol production by chemical modification of date seeds. Ind. Crops Prod. 34: 1035-1040.
Chandrasekaran, M. and A. H. Bahkali. 2013. Valorization of date palm (Phoenix dactylifera) fruit processing by-products and wastes using bioprocess technology review. Saudi J. Biol. Sci. 20: $105-120$.

Chao, C. T. and R. R. Krueger. 2007. The date palm (Phoenix dactylifera L.): Overview of biology, uses, and cultivation. HortScience. 42: 1077.

Daoud, A., D. Malika, S. Bakari, N. Hfaiedh, K. Mnafgui, A. Kadri and N. Gharsallah. 2019. Assessment of polyphenol composition, antioxidant and antimicrobial properties of various extracts of Date Palm Pollen (DPP) from two Tunisian cultivars. Arab. J. Chem. 12: 3075-3086.

Djaoud, K., L. Boulekbache-Makhlouf, M. Yahia, H. Mansouri, N. Mansouri, K. Madani, and A. Romero. 2020. Dairy dessert processing: Effect of sugar substitution by date syrup and powder on its quality characteristics. J. Food Proc. Preserv. 44: e14414.

El Hag, M. G. and K. M. Al Shargi. 1998. Comparative performance of goats and sheep fed on high-fiber pelleted diets supplemented with different nitrogen sources. J. Appl. Anim. Res. 13: 179-184.

Elleuch, M., S. Besbes, O. Roiseux, C. Blecker, C. Deroanne, N. E. Drira and H. Attia. 2008. Date flesh: Chemical composition and characteristics of the dietary fibre. Food Chem. 111: 676-682.

El-Nagga, E. A. and Y. A. Abd El-Tawab. 2012. Compositional characteristics of date syrup extracted by different methods in some fermented dairy products. Ann. Agric. Sci. 57: 29-36.

Elsanhoty, R. M., I. A. Al-Turki and M. F. Ramadan. 2012. Screening of medium components by Plackett-Burman design for carotenoid production using date (Phoenix dactylifera) wastes. Ind. Crops Prod. 36: 313-320.

Eoin, L. 2016. Systematics: Blind dating. Nat. Plants. 2: 16069.

FAOSTAT. 2018. Date, The Food and Agriculture Organization of the United Nations. Available from: http://www.faostat.fao.org/ faostat/en/\#data/QC. [Last accessed on 2020 Jun 10].

Farahnaky, A., M. Mardani, G. Mesbahi and M. Majzoobi. 2016. Some physicochemical properties of date syrup, concentrate, and liquid sugar in comparison with sucrose solutions. J. Agric. Sci. Technol. 18: 657-668.

Gheisari, H. R., S. Heydari and S. Basiri. 2020. The effect of date versus sugar on sensory, physicochemical, and antioxidant properties of ice cream. Iran. J. Vet. Res. 21: 9.

Glasner, B., A. Botes, A. Zaid and J. Emmens. 1999. Chapter IX Date Harvesting, Packing House Management and Marketing Aspects. In: FAO Plant Production and Protection Papers, 175205. The Food and Agriculture Organization, United Nations.

Hamada, J. S., I. B. Hashim and F. A. Sharif. 2002. Preliminary analysis and potential uses of date pits in foods. Food Chem. 76: 135-137.

Hazzouri, K. M., J. M. Flowers, H. J. Visser, H. S. M. Khierallah, U. Rosas, G. M. Pham, R. S. Meyer, C. K. Johansen, Z. A. Fresquez, K. Masmoudi, N. Haider, N. El Kadri, Y. Idaghdour, J. A. Malek, D. Thirkhill, G. S. Markhand, R. R. Krueger, A. Zaid and M. D. Purugganan. 2015. Whole genome re-sequencing of date palms yields insights into diversification of a fruit tree crop. Nat. Commun. 6: 8824.

Hussein, A. and H. Ali. 2017. Chemical and technological properties of improved snacks from oat and date seeds composite flour. Am. J. Food Technol. 12: 201-208.

Jaafar, K. A. 2010. Biogas production by anaerobic digestion of date palm pulp waste. Al-Khwarizmi Eng. J. 6: 14-20.

Jadhav, A., C. Holkar, A. Goswami, A. Pandit and D. Pinjari. 2016. Acoustic cavitation as a novel approach for extraction of oil from 
waste date seeds. ACS Sustain. Chem. Eng. 4: 8.

Jridi, M., N. Souissi, M. Ben Salem, M. A. Ayadi, M Nasri and S. Azabou. 2015. Tunisian date (Phoenix dactylifera L.) byproducts: Characterization and potential effects on sensory, textural and antioxidant properties of dairy desserts. Food Chem. 188: 8-15.

Kalbouneh, S. 2011. Cropping patterns as a tool for water resource management in Palestine: date palm cultivation in Jiftlik, Jordan Valley. Int. J. Environ. Stud. 68: 447-460.

Kazemalilou, S. and A. Alizadeh. 2017. Optimization of sugar replacement with date syrup in prebiotic chocolate milk using response surface methodology. Korean J. Food Sci. Anim. Resour. 37: 449-455.

Khiari, R., S. Dridi-Dhaouadi, C. Aguir and M. F. Mhenni. 2010. Experimental evaluation of eco-friendly flocculants prepared from date palm rachis. J. Environ. Sci. 22: 1539-1543.

Khiyami, M., S. Alfadul and A. Bahkali. 2011. Polyhydroxyalkanoates production via Bacillus PCS biofilm and date palm syrup. J. Med. Plant Res. 5: 3312-3320.

King, J. W. 2014. Modern supercritical fluid technology for food applications. Annu. Rev. Food Sci. Technol. 5: 215-238.

Lattieff, F. 2016. A study of biogas production from date palm fruit wastes. J. Cleaner Prod. 139: 1191-1195.

Lecheb, F. and S. Benamara. 2015. Feasibility study of a cosmetic cream added with aqueous extract and oil from date (Phoenix dactylifera L.) fruit seed using experimental design. J. Cosmet. Sci. 66: 1-12.

Lobo, G., E. Yahia and A. Kader. 2013. Biology and postharvest physiology of date fruit. In: M. Siddiq, S. M. Aleid and A. A. Kader (Ed.), Dates: Postharvest Science, Processing Technology and Health Benefits, John Wiley and Sons, Hoboken, New Jersey, pp. $57-80$.

Mahgoub, O., I. T. Kadim, D. S. Al-Ajmi, N. M. Al-Saqry, A. S. Al-Abri, A. R. Richie, K. Annamalai and N. E. Forsberg. 2004. The effects of replacing Rhodes grass (Chloris gayana) hay with Ghaf (Prosopis cineraria) pods on the performance of Omani native sheep. Trop. Anim. Health Prod. 36: 281-294.

Mahgoub, O., I. Kadim, E. Johnson, A. Srikandakumar, N. AlSaqri, A. Al-Abri and A. Ritchie. 2005. The use of concentrate containing Meskit (Prosopis juliflora) pods and date palm byproducts to replace commercial concentrate in diets of Omani sheep. Anim. Feed Sci. Technol. 120: 11.

Manickvasagan, A., S. Chandini, and Z. Al Attabi. 2018. Effect of sugar replacement with date paste and date syrup on texture and sensory quality of kesari (traditional Indian dessert). J. Agric. Mar. Sci. 22: 67.

Martín-Sánchez, A. M., G. Ciro-Gómez, E. Sayas, J. Vilella-Esplá, J. Ben-Abda and J. A. Pérez-Álvarez. 2013. Date palm by-products as a new ingredient for the meat industry: Application to pork liver pâté. Meat Sci. 93: 880-887.

Mohamed, S., M. Awad and A. Al-qurashi. 2014. Antioxidant activity, antioxidant compounds, antioxidant andhydrolytic enzymes activities of Barhee dates at harvest and duringstorage as affected by pre-harvest spray of some growth regulators. Sci. Hortic. 167: 91-99.

Mrabet, A., G. Rodríguez-Gutiérrez, R. Rodríguez-Arcos, R. GuillénBejarano, A. Ferchichi, M. Sindic and A. Jiménez-Araujo. 2016. Quality characteristics and antioxidant properties of muffins enriched with date fruit (Phoenix Dactylifera L.) fiber concentrates. J. Food Qual. 39: 237-244.

Myhara, R. M., D. I. Byerley, O. Mahgoub and J. M. Chesworth. 2000. Effects of testicular status and feeding diets containing date palm by-product on the sensory attributes of Omani lamb meat. Small Rumin. Res. 38: 57-61.

Nancib, N., A. Nancib and J. Boudrant. 1997. Use of waste date products in the fermentative formation of baker's yeast biomass by Saccharomyces cerevisiae. Bioresour. Technol. 60: 67-71.

Nasser, R. and H. Al-Mefarrej. 2011. Midribs of date palm as a raw material for wood-cement composite industry in Saudi Arabia. World Appl. Sci. J. 15: 1651-1658.

Nehdi, I., S. Omri, M. I, Khalil and S. I. Al-Resayes, S. I. 2010 Characteristics and chemical composition of date palm (Phoenix canariensis) seeds and seed oil. Ind. Crops Prod. 32: 360-365.

Nehdi, I., H. Sbihi, C. Tan, U. Rashid and S. Al-Resayes. 2018. Chemical composition of date palm (Phoenix dactylifera L .) seedo from six Saudi Arabian cultivars: Seed oil from Saudi Arabian cultivars. J. Food Sci. 83: 624-630.

Platat, C., H. M. Habib, I. B. Hashim, H. Kamal, F. AlMaqbali, U. Souka and W. H. Ibrahim. 2015. Production of functional pita bread using date seed powder. J. Food Sci. Technol. 52: 63756384.

Puri, A., R. Sahai, K. L. Singh, R. P. Saxena, J. S. Tandon and K. C. Saxena. 2000. Immunostimulant activity of dry fruits and plant materials used in indian traditional medical system for mothers after child birth and invalids. J. Ethnopharmacol. 71: 89-92.

Radwan, H., F. Alanazi, E. Taha, H. Dardir, I. Moussa and I. Alsarra. 2010. Development of a new medium containing date syrup for production of bleomycin by Streptomyces mobaraensis ATCC 15003 using response surface methodology. Afr. J. Biotechnol. 9: 5450-5459.

Razavi, S. M. A., M. B. H. Najafi and Z. Alaee. 2007. The time independent rheological properties of low fat sesame paste/date syrup blends as a function of fat substitutes and temperature. Food Hydrocoll. 21: 198-202.

Riahi, K., A. Ben Mammou and B. Ben Thayer. 2009. Date-palm fibers media filters as a potential technology for tertiary domestic wastewater treatment. J. Hazardous Mater. 161: 608-613.

Saadaoui, N., A. Rouilly, K. Fares and L. Rigal. 2013. Characterization of date palm lignocellulosic by-products and self-bonded composite materials obtained thereof. Mater. Des. 50: 302-308.

Sánchez-Zapata, E., J. Fernández-López, M. Peñaranda, E. FuentesZaragoza, E. Sendra, E. Sayas and J. A. Pérez-Alvarez. 2011. Technological properties of date paste obtained from date byproducts and its effect on the quality of a cooked meat product. Food Res. Int. 44: 2401-2407.

Sayed, A. F., A. Kholif and A. S. Gad. 2010. Evaluation of the nutritional value of functional yogurt resulting from combination of date palm syrup and skim milk. Am. J. Food Technol. 5: 259.

Shi, J., F. Shahidi and C. T. Ho. 2005. Asian Functional Foods, CRC Press, Boca Raton, Florida.

Siddiq, M. and I. Greiby. 2014. Overview of date fruit production, postharvest handling, processing, and nutrition. In: M. Siddiq, S. M. Aleid and A. A. Kader (Ed.), Dates: Postharvest Science, Processing Technology and Health Benefits, John Wiley and Sons, Hoboken, New Jersey, pp. 1-28.

Taleb, H., S. E. Maddocks, R. K. Morris and A. D. Kanekanian. 2016. The antibacterial activity of date syrup polyphenols against S. aureus and E. coli. Front. Microbiol. 7: 198-198.

Tammam, A. A., A. I. A. Mansour, K. H. Salman and F. E. El-Gazzar 2013. Preparation, and properties of bio-yoghurt containing date syrup (dibis). Egypt. J. Dairy Sci. 41: 69-76.

Tammam, A. A., K. H. Salman and A. M. Abd-El-Rahim. 2014. Date syrup as a sugar substitute and natural flavour agent in ice cream manufacture. J. Food Dairy Sci. 5: 625-632. 
Tang, Z. X., L. E. Shi and S. M. Aleid. 2013. Date fruit: Chemical composition, nutritional and medicinal values, products. J. Sci. Food Agric. 93: 2351-2361.

Tiwari, B. K., N. P. Brunton and C. Brennan. 2013. Handbook of Plant Food Phytochemicals: Sources, Stability and Extraction, John Wiley and Sons, , Hoboken, New Jersey.

Vandepopuliere, J. M., Y. Al-Yousef and J. J. Lyons. 1995. Dates and date pits as ingredients in broiler starting and coturnix quail breeder diets. Poult. Sci. 74: 1134-1142.
Vinatoru, M. 2001. An overview of the ultrasonically assisted extraction of bioactive principles from herbs. Ultrason. Sonochem. 8: 303-313.

Yangılar, F. 2015. Mineral contents and physical, chemical, sensory properties of ice cream enriched with date fibre. Ital. J. Food Sci. 27: 397-406.

Yousuf, R. G. and J. B. Winterburn. 2017. Waste date seed oil extract as an alternative feedstock for Poly(3-hydroxybutyrate) synthesis. Biochem. Eng. J. 127: 68-76. 